\title{
PENGEMBANGAN BANK SOAL BERBENTUK KARTU BERORIENTASI HOTS DI SD
}

\author{
DEVELOPMENT OF CARD FORMED OF STUDY EXERCISES \\ COMPILATION ORIENTED BY HOTS IN ELEMENTARY SCHOOL
}

\author{
Alifia Laily Safrina ${ }^{* 1}$, Sari Yustiana ${ }^{2}$, Muhamad Afandi ${ }^{3}$ \\ ${ }^{1,2,3}$ Program Studi Pendidikan Guru Sekolah Dasar, Fakultas Keguruan dan Ilmu Pendidikan, \\ Universitas Islam Sultan Agung Semarang, Indonesia \\ e-mail: ${ }^{* 1}$ alifalailys@std.unissula.com, ${ }^{2}$ sari.yustiana@unissula.ac.id, ${ }^{3}$ mafand@unissula.ac.id
}

\begin{abstract}
ABSTRAK
Evaluasi sangat penting karena untuk memperoleh penilaian pada aktivitas peserta didik. Penelitian ini untuk mengembangkan dan mengetahui kelayakan produk bank soal berbentuk kartu berorientasi HOTS. Produk bank soal berbentuk kartu dikembangkan berdasarkan kebutuhan guru terhadap sumber referensi lain dalam pembelajaran dan merupakan jenis penelitian Research and Development (R\&D). Pengembangan produk bank soal berbentuk kartu menggunakan prosedur pengembangan menurut Puspendik yang berisi delapan tahapan. Hasil validasi dari 47 butir soal pada bank soal diperoleh hasil penelitian sebagai berikut. (1) Hasil validasi dari 3 ahli diperoleh rata-rata skor 0,83 dengan kriterian "Sangat Valid". (2) Hasil validasi produk diperoleh rata-rata 0,81 dengan kriteria "Sangat Valid". (3) Hasil 47 butir soal uraian yang divalidasi diperoleh rata-rata 0,81 dengan kriteria "Sangat Valid". (4) Hasil angket respons guru diperoleh rata-rata 1,00 dengan kriteria "Sangat Valid", sedangkan hasil angket respons peserta didik memperoleh skor 5 pada setiap peserta didik. (5) Hasil validitas soal memperoleh rata-rata 0,44 dengan kriteria "Cukup". (6) Hasil reliabilitas memperoleh skor 0,579 dengan kriteria "Cukup". (7) Hasil tingkat kesukaran diperoleh skor 0,49 dengan kriteria "Sedang”. (8) hasil daya pembeda diperoleh skor 0,61 dengan kriteria "Baik".
\end{abstract}

Kata kunci: bank soal, kartu soal, HOTS

\begin{abstract}
To obtain assessment of students' activities evaluation is required. Therefore, this study is conducted to develop and understand the product feasibility of card formed of study exercises compilation oriented by HOTS. This product is developed according to teachers' need towards other references in learning. Also this is a Research and Development $(R \& D)$ study. The development of the product applies development procedures, used by Puspendik. According to validation test results of 47 questions in exercises we obtained: (1) validation test of 3 experts shows "Strongly Valid" with 0.83 average score; (2) validation test of product shows "Strongly Valid" with 0.81 average score; (3) validation test of 47 questions shows "Strongly Valid" with 0.81 average score; (4) validation test of questionnaire for teachers' responses shows "Strongly Valid" with 1.00 average score, nevertheless validation test of questionnaire for students' responses has 5 score on each student; (5) validation test of questions in exercises shows "Sufficient" with 0.44 average score; (6) reliability test shows "Sufficient" with 0.579 average score; (7) validation test of difficulty level of exercises shows "Medium" with 0.49 score; and (8) validation test of distinguish ability shows "Good" with 0.61 score.
\end{abstract}

Keywords: study exercises compilation, card formed exercises, HOTS 


\section{PENDAHULUAN}

Perkembangan pendidikan perlu diimbangi peran guru Sekolah Dasar dalam menciptakan sumber daya manusia yang berkualitas dan berdaya saing tinggi. Oleh sebab itu, peserta didik, khususnya di Sekolah Dasar sudah semestinya dibekali dengan kemampuan analisis, evaluasi, kreasi, serta logika penalaran, atau saat ini disebut dengan HOTS (Higher Orders Thinking Skills). Aplikasi HOTS tercermin dalam soal dengan proses formulate (merumuskan), dengan kata lain, soal yang menggunakan kata kerja merumuskan termasuk ke dalam level HOTS teratas yaitu create [1].

Create atau mencipta terdapat pada level C6 dari tiga level HOTS yaitu C4, C5, dan C6. Level tersebut didapatkan ketika peserta didik mendapatkan penilaian evaluasi atau penilaian kognitif. Penilaian kompetensi peserta didik, khususnya pada ranah kognitif, dapat merujuk pada draf penilaian yang terdapat di buku pegangan guru [2]. Dengan demikian, penilaian yang dilakukan terhadap peserta didik dapat menggunakan draf penilaian, tetapi pada pengembangan hanya berfokus pada peniaian evaluasi saja.

Pada Kurikulum 2013 ini terdapat tiga ranah yang tidak dapat dipisahkan, yaitu ranah kognitif, afektif, dan psikomotor. Sejalan dengan perkembangan pembelajaran saat ini, penggunaan kurikulum 2013 sangat mendukung adanya pembelajaran sikap [3]. Namun demikian, ketiga ranah tersebut perlu diterapkan sesuai dengan porsinya tanpa mengurangi salah satunya [4]. Penilaian kognitif salah satu penilaian pengetahuan pada Kurikulum 2013. Penilaian ranah kognitif ini akan mengukur ketercapaian pengetahuan yang dimiliki oleh peserta didik.

Penilaian kognitif secara umum berkaitan dengan kemampuan peserta didik untuk berpikir kreatif, kritis, kemampuan berargumen, dan kemampuan mengambil keputusan yang merupakan cakupan dari HOTS. HOTS merupakan suatu proses berpikir peserta didik dalam level kognitif yang lebih tinggi yang dikembangkan dari berbagai konsep dan metode kognitif dan taksonomi pembelajaran seperti metode problem solving, taksonomi bloom, dan taksonomi pembelajaran, pengajaran, dan penilaian [5]. Dengan demikian, dapat diketahui bahwa tujuan utama dari HOTS adalah meningkatkan kemampuan berpikir peserta didik pada level yang lebih tinggi. Kemampuan berpikir tingkat tinggi yang dimaksud mencakup kemampuan untuk berpikir secara kritis dala menerima berbagai jenis informasi, berpikir kreatif dalam memecahkan suatu masalah menggunakan pengetahuan yang dimiliki serta membuat keputusan dalam situasi-situasi yang kompleks.

Penelitian ini bertujuan mengembangkan bank soal berbentuk kartu yang berorientasi HOTS untuk memudahkan guru dalam evaluasi dan menarik peserta didik. Selain itu, kondisi jenuh peserta didik dapat diantisipasi dengan penggunaan permainan agar lebih memudahkan peserta didik. Hal ini diperkuat oleh hasil penelitian yang sebelumnya pernah dilakukan, bahwa permainan terbukti efektif meningkatkan kompetensi tertentu dalam diri peserta didik [6]. Penggunaan media yang tepat dalam proses pembelajaran tentu akan memperpudah pencapaian tujuan pembelajaran [7]. Dengan demikian, pengembangan bank soal kartu diharapkan dapat membuat peserata didik mengikuti pembelajaran Bahasa Indonesia secara efektif dan menyenangkan.

Wawancara yang dilakukan dengan guru di kelas IV SDN Gebangsari 01,didapatkan data kurangnya pemahaman peserta didik ketika guru memberikan soal berbasis HOTS. Sebagian juga peserta didik masih kurang paham untuk menjawab soal berbasis HOTS tersebut, peserta didik juga kadang-kadang malu bertanya mengenai soal berbasis HOTS, hal ini yang dirasakan oleh wali kelas IV. Adanya masalah tersebut tentu memperlambat proses belajar mengajar, termasuk dalam penyelesaian soal HOTS. Tanggapan mengenai adanya soal HOTS ini juga dipaparkan oleh wali kelas IV yaitu membangun peserta didik, menambah wawasan, melatih peserta didik agar tidak grogi dalam menghadapi soal-soal. Akan tetapi, kelebihan tersebut, menurut orangtua peserta didik tidak dibarengi dengan penyediaan soal-soal yang memadai. 
Jurnal Ilmiah KONTEKSTUAL, Volume.2, No.02, Februari 2021, pp. 1-8

Kurangnya pengembangan bank soal berbasis HOTS terutama pada mata pelajaran Bahasa Indonesia pada kelas IV membuat pemahaman dalam menjawab soal berbasis HOTS masih kurang. Oleh sebab itu, untuk bisa membuat pemahaman peserta didik meningkat dalam menjawab soal berbasis HOTS, dibutuhkan evaluasi yang inovatif. Evaluasi yang bisa digunakan untuk meningkatkan pemahaman peserata didik untuk menjawab soal berbasis HOTS yaitu dengan menggunakan bank soal berbentuk kartu yang berorientasi HOTS.

\section{METODE PENELITIAN}

Penelitian ini dilaksanakan di Sekolah Dasar berdasarkan kebutuhan guru dan peserta didik dengan menggunakan R\&D (Research and Development). Research and Development adalah kombinasi metode kualitatif dan kuantitatif [8]. Selanjutnya, desaian penelitian yang digunakan merujuk pada tahap-tahap pengembangan butir soal. Adapun langkah-langkah pengembangan butir soal tersebut meliputi: (1) penentuan tujuan tes; (2) penulisan kisi-kisi; (3) penulisan soal; (4) analisis kualitatif; (5) perakitan soal; (6) ujicoba soal: (7) analisis kuantitatif; (8) bank soal [9].

Data didapatkan dengan cara observasi dan wawancara terhadap guru dan peserta didik kelas IV untuk memperoleh permasalahan dalam evaluasi pembelajaran di kelas pada Kurikulum 2013. Sumber dalam penelitian ini adalah guru dan peserta didik kelas IV, dengan jumlah 10 peserta didik. Laki-laki berjumlah 3, perempuan berjumlah 7 peserta didik. Teknik analisis data pada penelitian ini adalah validasi produk, validasi ahli, validasi respons guru dan validasi respons peserta didik.

Uji kelayakan pada penelitian ini dilakukan dengan tiga pengujian, yaitu: uji validasi ahli, analisis kualitatif, dan analisis kuantitatif. Yang menjadi penguji bagi uji validasi adalah 2 dosen dan 1 guru. Teknik analisis data yang digunakan pada penelitian ini tertuju pada dua data yaitu deskriptif kualitatif dan analisis kuantitatif. Analisis skor ini untuk mengetahui persentase angket yang akan diberikan untuk validator dengan memakai langkah uji validasi ahli, validasi produk, angket respons guru, angket respons peserta didik. Selanjutnya, angket butir soal uraian meliputi validasi soal, reliabilitas soal, daya pembeda dan tingkat kesukaran soal [10].

\section{HASIL DAN PEMBAHASAN}

\section{Hasil Penelitian}

Jenis penelitian yang digunakan dalam pengembangan alat evauasi ini adalah penelitian dan pengembangan atau research and development $(R \& D)$. Dalam penelitian ini digunakan prosedur penelitian pengembangan yang terdiri atas delapan langkah. Hasil pelaksanaan langkah-langkah itu adalah sebagai berikut.

1. Tujuan Tes

Tujuan tes adalah untuk dapat mengembangkan kemampuan berpikir tingkat tinggi pada peserta didik. Hasil wawancara yang telah dilakukan juga menunjukkan belum banyak soal berorientasi Hots yang tersedia bagi peserta didik. Hal ini diperkuat dari hasil observasi yang dilakukan di kelas IV diperoleh masalah berupa kurangnya soal yang berbasis HOTS pada muatan Bahasa Indonesia, sehingga guru membutuhkan evaluasi yang inovatif.

2. Penulisan Kisi-kisi

Kisi-kisi merupakan jabaran dari Kompetensi Dasar (KD), Standar Kompetensi (SK), Standar Kompetensi Mata Pelajaran (SKL-MP).

3. Penulisan soal

Tahap selanjutnya adalah penulisan soal. Penulisan soal dalam pembuatan bank soal berbentuk kartu soal ini berupa tes uraian. Dalam tahap ini diharpakan peserta didik dapat memecahkan masalah soal yang berbasis HOTS pada muatan Bahasa Indonesia. Soal yang disajikan berbentuk uraian, adapun contoh soal yang dikembagkan adalah sebagai berikut. 
"Di kota Jawana Kabupaten Pati, tradisi Larung Sesaji sering disebut dengan istilah Lomban Kupatan, disebut seperti itu karena salah satu kegiatan tradisi Larung Sesaji di kota Jawana ada lomba menangkap bebek di sungai dengan balap dayung atau disebut Lomban. Mengapa di Daerah Pati tradisi larung saji disebut dengan Lomban Kupatan?"

Contoh soal yang disajikan termasuk dalam katagori soal HOTS. Soal tersebut merupakan soal ranah kognitif pada tingkat C5 (mengevaluasi). Hal ini dapat dilihat dari pertanyaan yang menanyakan terkait alasan yang ditunjukkan dengan kata tanya 'mengapa'.

4. Analisis Kualitatif

Analisis kualitatif bertujuan menetahui soal tersebut layak digunakan atau tidak. Aspek yang harus diperhatikan dalam menyusun soal uraian adalah materi, konstruksi, aspek bahasa, dan budaya. Berdasarkan masukan dari validator terhadap produk bank soal berbetuk kartu soal, terdapat beberapa catatan perbaikan terhadap produk sebagai berikut.

a. Perbaikan Ejaan

Berdasarkan catatan dari validator masih terdapat ejaan yang belum sesuai dengan PUEBI.

b. Penggunaan Kalimat Efektif

Penggunaan kalimat efektif pada kalimat soal masih berbelit-belit dan tidak efektif.

c. Penyusunan Kalimat Jawaban

Berdasarkan catatan dari validator masih ditemukan catatan untuk penyusunan kalimat jawaban yang belum tepat.

d. Soal Open Ended

Sebelum dilakukan perbaikan, soal belum mengarah ke open ended yaitu soal yang memancing peserta didik untuk memecahkan sebuah masalah.

e. Warna Kurang Menarik

Berdasarkan catatan dari validator warna yang digunakan di produk masih berwarna gelap dan kurang soft, maka warna diperbaiki lagi menjadi lebih soft.

5. Perakitan Soal

Tahap perakitan soal membutuhkan banyak butir soal karena untuk menjadi suatu alat ukur yang terpadu. Perakitan soal pada muatan Bahasa Indonesia berbasis HOTS bertujuan mengevaluasi peserta didik. Jumlah soal yang dibuat disesuaikan dengan aturan Puspendik yaitu $20-25 \%$, tetapi pada penelitian ini hanya dibatasi untuk memakai bobot soal $25 \%$. Pada muatan Bahasa Indonesia soal dibuat sebanyak 47 butir, mempunyai 6 Kompetensi Dasar (KD) dan untuk penskoran soal uraian berbasis HOTS menggunakan skala skor 1-5. Pengukuran yang digunakan soal uraian untuk mendapatkan hasil yang valid adalah validitas, reliabilitas, tingkat kesukaran, dan daya pembeda. Berikut contoh soal yang dikembangkan

\begin{tabular}{|c|c|}
\hline \multicolumn{2}{|r|}{ KARTU SOAL BERBASIS HOTS MUATAN BAHASA INDONESIA } \\
\hline Semester & $: 1$ \\
\hline Kelas & : IV (empat) \\
\hline Kompetensi Inti & $\begin{array}{l}\text { : Memahami pengetahuan faktual dengan cara mengamati dan menanya berdasarkan rasa } \\
\text { ingin tahu tentang dirinya, makhluk ciptaan Tuhan dan kegiatannya, dan benda-benda yang } \\
\text { ingin dijumpainya di rumah, di sekolah dan di tempat bermain. }\end{array}$ \\
\hline Kompetensi Dasar & : 3.2 Mencermati keterhubungan antargagasan yang didapat dari teks lisan, tulis, atau visual. \\
\hline Indikator Soal & : 3.2.1 Mengidentifikasi informasi dari teks visual yang diamati \\
\hline Kisi-kisi & : menjelaskan alasan dari informasi yang didapa \\
\hline \multicolumn{2}{|c|}{$\begin{array}{l}\text { Di kota Jawana Kabupaten Pati, tradisi Larung Sesaji sering disebut dengan istilah Lomban Kupatan, disebut seperti } \\
\text { itu karena salah satu kegiatan tradisi Larung Sesaji di kota Jawana ada lomba menangkap bebek di sungai dengan } \\
\text { balap dayung atau disebut Lomban. }\end{array}$} \\
\hline \multirow{2}{*}{\multicolumn{2}{|c|}{$\begin{array}{l}\text { Mengapa di Daerah Pati tradisi larung saji disebut dengan Lomban Kupatan? (C5: Mengevaluasi) } \\
\text { Jawaban : Karena salah satu kegiatan tradisi Larung Sesaji di kota Jawana ada lomba menangkap bebek di sungai } \\
\text { dengan balap dayung atau disebut Lomban. }\end{array}$}} \\
\hline & \\
\hline Penskoran & \\
\hline 1:tidak tepat & 3:cukup 4: tepat \\
\hline
\end{tabular}

Gambar 1. Contoh soal HOTS dalam Kartu 
Jurnal Ilmiah KONTEKSTUAL, Volume.2, No.02, Februari 2021, pp. 1-8

6. Uji Coba Soal

Uji coba soal sangat penting karena untuk mengetahui kelayakan pada setiap butir soal. Uji coba soal yang dilakukan untuk mengetahui validitas, reliabilitas, tingkat kesukaran, dan daya pembeda. Mengingat keterbatasan waktu penelitian, uji coba soal hanya dilakukan sampai uji coba terbatas, tidak sampai pada tahap uji coba luas. Peneliti melakukan uji coba terbatas kepada 10 peserta didik kelas IV, yang terdiri atas perempuan 7 peserta didik, dan laki-laki berjumlah 3 peserta didik. Peserta didik mengikuti dengan baik. Ada beberapa peserta didik yang belum paham dan beberapa sudah bisa menjawab tanpa bertanya.

7. Analisis Kuantitatif

Angket validasi ahli divalidasi oleh 2 dosen dan 1 guru diperoleh hasil 0,83 dengan kriteria "Sangat Valid". Dengan beberapa catatan seperti penggunaan kalimat efektif, perbaikan ejaan dan kisi-kisi jawaban. Validasi produk memperoleh rata-rata 0,81 dengan kriteria "Sangat Valid". Dengan catatan warna pada kartu soal kurang menarik. Selanjutnya terdapat angket validasi butir soal uraian memperoleh hasil 0,81 dengan kriteria "Sangat Valid", dengan catatan seperti soal kurang mengarah ke open ended. Selanjutnya respons guru divalidasi oleh 1 guru memperoleh skor 1,00 dengan kriteria"Sangat Valid". Dan respons peserta didik yang divalidasi oleh 10 peserta didik, yang setiap peserta didik memperoleh skor 5.

Sementara itu untuk mengukur soal uraian terdapat beberapa aspek pengukuran seperti validitas soal, reliabilitas, tingkat kesukaran, dan daya pembeda.

a. Validitas soal memperoleh kriteria "Rendah" sebanyak 22 butir soal, kriteria "Cukup" sebanyak 19 butir soal, dan kriteria "Tinggi" berjumlah 6 butir soal. Rata-rata yang diperoleh dari validitas soal tersebut adalah 0,44 dengan kriteria "Cukup".

b. Reliabilitas ditentukan dari nilai jumlah skor tertinggi yaitu 221, dan nilai terendah 165 ; sedangkan rata-rata skor yang didapat yaitu 192,4. Selanjutnya memperoleh korelasi 0,407 . Hasil reliabilitas soal pada soal uraian berbasis HOTS pada muatan Bahasa Indonesia memperoleh 0,579 dengan kriteria "Cukup".

c. Tingkat kesukaran memperoleh kriteria "Sulit" sebanyak 16 butir soal, kriteria "Sedang" 22 butir soal, dan kriteria "Mudah" sebanyak 9 butir soal. Rata-rata yang diperoleh dari tingkat kesukaran adalah 0,49 dengan kriteria "Sedang".

d. Daya pembeda memperoleh kriteria "Jelek" sebanyak 10 butir soal, kriteria "Cukup" 10 butir, kriteria "Baik" 11 butir soal, dan kriteria "Baik Sekali" 16 butir soal. Rata-rata yang diperoleh dari daya pembeda yaitu 0,61 dengan kriteria "Baik".

8. Bank Soal

Setelah melalui beberapa validasi dan didapatkan hasil dari beberapa pihak, dihasilkan produk bank soal berbentuk kartu soal berbasis HOTS muatan Bahasa Indonesia kelas IV dengan ciri tesnya berbentuk tes uraian, yang berguna untuk evaluasi peserta didik. Berikut hasil bank soal berbentuk kartu soal pada muatan Bahasa Indonesia kelas IV

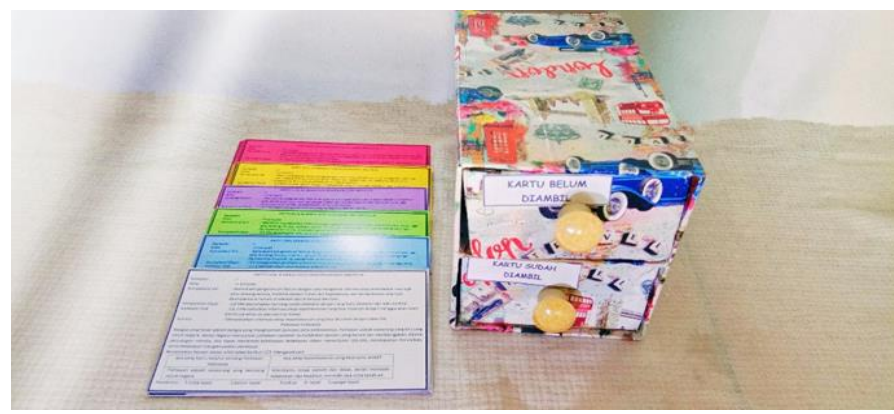

Gambar 2. Kartu Soal dan Tempatnya 


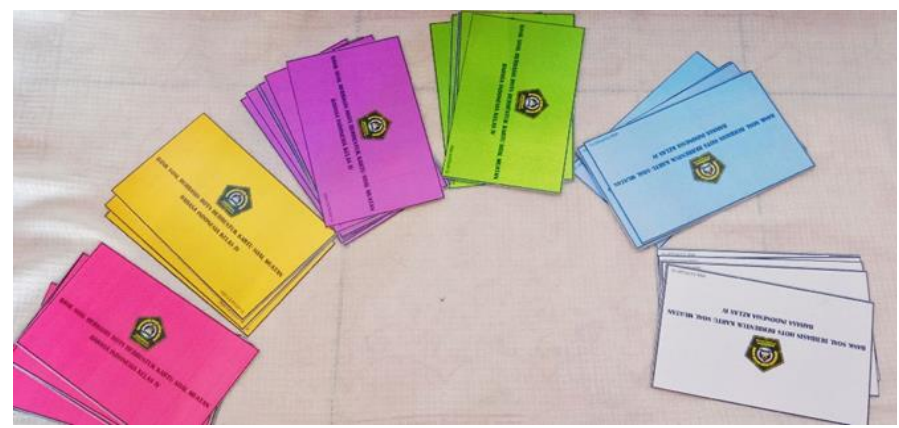

Gambar 3 Kartu Soal Tampak Belakang

\section{Pembahasan}

Pengembangan produk bank soal berbentuk kartu soal dapat membantu guru dalam melakukan evaluasi peserta didik. Pada pengembangan alat evaluasi ini, terkait dengan tugasnya guru mempunyai peran yang sangat besar, dan peserta didik pun dapat berperan aktif dalam pembelajaran. Suatu tes yang digunakan dalam proses penilaian tentu harus berkualitas baik dan tes tersebut benar-benar dapat mengukur kemampuan peserta didik yang sebenarnya [11]. Dengan adanya bank soal ini, dapat dipilih kualitas soal tes uraian yang baik dan berkualitas.

Berdasarkan perhitungan tersebut, produk dinyatakan sebagai bahan evaluasi yang layak, keberhasilan dalam penelitian ini dapat diketahui dengan menggunakan beberapa langkah pengujian sehingga mencapai kelayakan. Kepraktisan produk bank soal tersebut dilihat dari adanya beberapa aspek di antaranya adalah kartu soal disajikan secara menarik. Kartu soal ini dapat menarik peserta didik untuk mengikuti evaluasi pada muatan Bahasa Indonesia yang diberikan oleh guru.

Pengembangan bank soal berbentuk kartu soal ini membantu guru untuk mempermudah proses evaluasi peserta didik. Adanya evaluasi pembelajaran untuk guru maupun peserta didik, dalam penelitian ini dikembangkan produk bank soal berbentuk kartu soal. Evaluasi dan pembaharuan terhadap bank soal menjadi sebuah proses yang penting dalam menjamin kualitas bank soal dan bobot program penilaian [12]. Dengan adanya bank soal berbentuk kartu soal ini diharapkan guru dapat mudah untuk melakukan evaluasi pembelajaran dan mempermudah untuk penilaian peserta didik.

Hasil penelitian menunjukan kemampuan berpikir kritis peserta didik dalam menyelesaikan soal HOTS materi barisan dan deret aritmatika dari empat soal yang diberikan masih tergolong sangat rendah. Berdasarkan hasil tes dan wawancara dari ketiga subjek menunjukan bahwa peserta didik lebih cenderung merasa kesulitan pada saat memasuki tahap menganalisis dan mengevaluasi. Peserta didik sering lupa dengan konsep yang terkait dengan soal sehingga menyulitkan mereka untuk menyelesaiakan soal apalagi soal yang berbentuk soal HOTS yang lebih bersifat kontekstual dan membutukan kemampuan untuk menganalisis dan mengevaluasi yang tinggi

Penyajian soal yang disajikan dalam kartu soal adalah berbentuk HOTS yang akan mendorong peserta didik berpikir kiritis. Hal ini karena soal HOTS membuat peserta didik menganalisis dan mengevaluasi soal sebelum menjawabnya, sehingga dapat mendorong peserta didik berpikir kritis [13]. HOTS juga akan mendung peserta didik secara luas dan mendalam tentang materi pelajaran. Oleh sebab itu, pengembangan bank soal berbentuk kartu soal yang berorientasi HOTS akan dapat mengembangkan kemampuan berpikir tingkat tinggi peserta didik.

Penyajian soal HOTS pada umumnya disajikan dalam soal-soal sains, tetapi tidak menutup kemungkinan soal HOTS juga dapat disajikan dimuatan sosial dan bahasa. Penyajian soal HOTS dalam muatan bahasa akan mendorong peserta didik lebih cermat dalam membaca teks bacaan. Hal ini tentu akan dapat meningkatkan minat baca peserta didik, karena salah satu factor yang mempengaruhi minat baca tersebut adalah faktor perhatian [14]. Saat peserta didik 
Jurnal Ilmiah KONTEKSTUAL, Volume.2, No.02, Februari 2021, pp. 1-8

mencermati soal HOTS yang disajikan, peserta didik akan memperhatikan bagian soal sehingga diharapkan minat bacanya juga berkembang.

\section{SIMPULAN}

Berdasarkan hasil dan pembahasan dapat disimpulkan bahwa kualitas produk dinyatakan layak digunakan sebagai evaluasi dibuktikan dengan hasil validasi yang dinilai oleh validator 2 dosen dan 1 guru. Validasi ahli memperoleh skor 0,83 dengan kriteria "Sangat Valid". Validasi produk memperoleh skor 0,81 dengan kriteria "Sangat Valid". Analisis data butir soal uraian memperoleh skor 0,44 dengan kriteria "Cukup", reliabilitas mendaptkan skor 0,579 dengan kriteria "Cukup", tingkat kesukaran memperoleh rata-rata 0,49 dengan kriteria "Soal Sedang", dan daya pembeda memperoleh hasil skor 0,61 dnegan kriteria "Baik".

Selanjutnya respons peserta didik berupa menjawab pernyataan "Ya" dengan memilih skor 1. Respons guru memperoleh skor 5 dengan tiap-tiap rating penilaian 4 dan rata-rata skor 1,00 dengan kriteria "Sangat Valid". Dinyatakan praktis digunakan oleh guru untuk evaluasi muatan Bahasa Indonesia berbasis HOTS. Pengembangan produk ini hanya sebatas kelayakan dan kepraktisan saja. Penelitian selanjutnya diharapkan dapat dikembangkan lagi, dan produk hasil penelitian ini diharapkan bisa bermanfaat bagi guru, peserta didik, dan sekolah.

\section{DAFTAR PUSTAKA}

[1] T. Hartini, M. A. Misri, and I. Nursuprianah, "Pemetaan Hots Siswa Berdasarkan Standar Pisa dan Timss untuk Meningkatkan Mutu Pendidikan," Eduma, vol. 5, no. 2, pp. 83-92, 2016, [Online]. Available: https://syekhnurjati.ac.id/jurnal/index.php/eduma/article/view/2795.

[2] S. Yustiana, "Instrumen Penilaian Otentik Berbasis Contextual Teaching and Learning Pada Subtema Keindahan Alam Negeriku Siswa Sekolah Dasar," Assessment and Research on Education, vol. 1, no. 1, pp. 32-45, 2019, [Online]. Available: https://ejournal.ressi.id/index.php/arisen/article/view/23.

[3] S. Mardikarini and L. C. K. Putri, "Pemantauan Kedisiplinan Siswa Melalui Penetapan Indikator Perilaku Disiplin Siswa Kelas III," Jurnal Ilmiah KONTEKSTUAL, vol. 2, no. 01, pp. 30-37, 2020, [Online]. Available: http://jurnal.umus.ac.id/index.php/kontekstual/article/view/246.

[4] S. Mardikarini and F. Hamdani, "Pelaksanaan Penilaian Pembelajaran Menggunakan Kurikulum 2013 di SD Negeri 1 Tapak," Jurnal Ilmiah KONTEKSTUAL, vol. 01, no. 1, pp. 70-76, 2019, [Online]. Available: http://jurnal.umus.ac.id/index.php/kontekstual/article/view/61.

[5] R. P. Wibawa and D. R. Agustina, "Peran Pendidikan Berbasis Higher Order Thinking Skills (Hots) Pada Tingkat Sekolah Menengah Pertama di Era Society 5.0 Sebagai Penentu Kemajuan Bangsa Indonesia," Equilibrum, vol. 7, no. 2, pp. 137-141, 2019, [Online]. Available: https://www.researchgate.net/publication/346113868_Peran_Pendidikan_Berbasis_High er_Order_Thinking_Skills_Hots_Pada_Tingkat_Sekolah_Menengah_Pertama_di_Era_S ociety_50_Sebagai_Penentu_Kemajuan_Bangsa_Indonesia.

[6] A. Mumpuni and A. Supriyanto, "Pengembangan Kartu Domino Sebagai Media Pembelajaran Kosakata Bagi Siswa," Sekolah Dasar: Kajian Teori dan Praktik Pendidikan, vol. 29, no. 1, pp. 88-101, 2020, [Online]. Available: http://journal2.um.ac.id/index.php/sd/article/view/12645.

[7] F. Fembriani, T. R. Koroh, P. Pasmiyati, and R. Polin, "Efektifitas Edmodo Terhadap Hasil Belajar Mahasiswa PGSD Universitas Nusa Cendana," Jurnal Ilmiah KONTEKSTUAL, vol. 2, no. 01, pp. 8-14, 2020, [Online]. Available: 
http://jurnal.umus.ac.id/index.php/kontekstual/article/view/243.

[8] A. Agussalim, D. Darwis, N. Noer, and N. Najib, "Development of Translating Software Makassar Language into the Indonesian Language Grammar- Based," International Journal of Science and Research, vol. 7, no. 6, pp. 748-757, 2015, [Online]. Available: https://www.ijsr.net/archive/v7i6/ART20183242.pdf.

[9] B. Kartowinangun, "Penulisan Butir Soal," Yogyakarta, 2012.

[10] M. Afandi, Evaluasi Pembelajaran Sekolah Dasar. Semarang: Unissula Press, 2013.

[11] N. Hayati and D. Mardapi, "Pengembangan Butir Soal Matematika SD di Kabupaten Lombok Timur Sebagai Upaya dalam Pengadaan Bank Soal," Jurnal Kependidikan, vol. 44, no. 1, pp. 26-38, 2014, [Online]. Available: https://journal.uny.ac.id/index.php/jk/article/view/2189.

[12] S. Ajrini, T. A. Kurniawan, and D. S. Rusdianto, "Pembangunan Sistem Pengelolaan Bank Soal Ujian Pilihan Ganda Secara Online," Jurnal Pengembangan Teknologi Informasi dan Ilmu Komputer, vol. 1, no. 9, pp. 980-988, 2017, [Online]. Available: http://j-ptiik.ub.ac.id/index.php/j-ptiik/article/view/296.

[13] F. Kempirmase, C. S. Ayal, and D. A. Ngilawajan, "Kemampuan Berpikir Kritis Siswa Dalam Menyelesaikan Soal-Soal Higher Order Thinking Skill (Hots) Pada Materi Barisan Dan Deret Aritmatika Di Kelas Xi Sma Negeri 10 Ambon," Prosiding Seminar Nasional Pendidikan Matematika Universitas Pattimura, vol. 1, no. Vol 1 (2019): Prosiding Seminar Nasional Pendidikan Matematika Universitas Pattimura, pp. 21-24, 2019, [Online]. Available: https://ojs3.unpatti.ac.id/index.php/mathedu/article/view/1610.

[14] A. Mumpuni and R. U. Nurbaeti, "Analisa Faktor yang Mempengaruhi Minat Baca Mahasiswa PGSD," DWIJA CENDEKIA: Jurnal Riset Pedagogik, vol. 4, no. 1, pp. 114124, 2020, [Online]. Available: https://jurnal.uns.ac.id/jdc/article/view/35229. 